\title{
Resource Use Efficiency of Wheat in Betul District of Madhya Pradesh
}

\author{
A. N. Gautam*, R. M. Sahu, Nidhi Sirothiya \\ Department of Agricultural, Economics and Farm Management, Jawaharlal Nehru Agricultural University (JNKVV), India
}

Copyright $\bigcirc 2017$ by authors, all rights reserved. Authors agree that this article remains permanently open access under the terms of the Creative Commons Attribution License 4.0 International License

\begin{abstract}
The present study is an attempt to examine resource use efficiency of wheat crop in Betul district of Madhya Pradesh and also identify of the constraints encountered in production of wheat by the farmers to achieve the potential yield of wheat. The study was conducted in 2013-14 and the results reveals that human labour was found significant for large (0.419) and overall (0.156) farm, while it non-signification for small and medium farms. Machine labour was found significant for all size of farms i.e. small (0.551) medium (0.526) large (0.370) and overall (0.687) farm size. Seed and fertilizer was found significant for small and overall farm. In case of marginal value productivity it was found that in small size farm the factors of production i.e. machine labour $\left(\mathrm{X}_{2}\right)$, seed $\left(\mathrm{X}_{3}\right)$, fertilizers $\left(\mathrm{X}_{4}\right)$ and
\end{abstract}

irrigations $\left(\mathrm{X}_{5}\right)$ had been found underutilized, whereas human labour $\left(\mathrm{X}_{1}\right)$ implying over utilization under the study area. The constraints related to wheat production i.e. high price of quality seed was reported by $68 \%$ farmers followed by lack of knowledge about nutrient content $67 \%$, high price of fertilizer $60 \%$, lack of knowledge of seed treatment $55 \%$ etc. were found major constraints.

Keywords Resource Use Efficiency, Wheat

\section{Introduction}

Table 1. Area, Production and Yield of Wheat during 2011-12 and 2012-13

\begin{tabular}{|c|c|c|c|c|c|c|}
\hline & \multicolumn{3}{|c|}{2012 to 2013} & \multicolumn{3}{|c|}{2011 to 2012} \\
\hline State & $\begin{array}{c}\text { Area (Million } \\
\text { hectares) }\end{array}$ & $\begin{array}{c}\text { Production } \\
\text { (Million Tonnes) }\end{array}$ & $\begin{array}{l}\text { Yield } \mathrm{Kg} / \\
\text { Hectare }\end{array}$ & $\begin{array}{c}\text { Area (Million } \\
\text { hectares) }\end{array}$ & $\begin{array}{c}\text { Production } \\
\text { (Million Tonnes) }\end{array}$ & $\begin{array}{l}\text { Yield Kg/ } \\
\text { Hectare }\end{array}$ \\
\hline Uttar Pradesh & 9.73 & 30.3 & 3114 & 9.73 & 30.29 & 3113 \\
\hline Punjab & 3.52 & 16.11 & 4577 & 3.53 & 17.28 & 4895 \\
\hline Madhya Pradesh & 5.3 & 13.13 & 2477 & 4.89 & 11.54 & 2360 \\
\hline Haryana & 2.5 & 11.12 & 4448 & 2.52 & 12.69 & 5036 \\
\hline Rajasthan & 2.82 & 8.95 & 3174 & 2.94 & 9.32 & 3170 \\
\hline Bihar & 2.22 & 5.38 & 2423 & 2.14 & 4.73 & 2210 \\
\hline Gujarat & 1.05 & 3.14 & 2990 & 1.35 & 4.07 & 3015 \\
\hline West Bengal & 0.32 & 0.91 & 2844 & 0.32 & 0.87 & 2719 \\
\hline Maharashtra & 0.59 & 0.88 & 1492 & 0.84 & 1.31 & 1560 \\
\hline Uttarakhand & 0.36 & 0.84 & 2333 & 0.37 & 1.31 & 2378 \\
\hline Himachal Pradesh & 0.36 & 0.54 & 1500 & 0.36 & 0.6 & 1667 \\
\hline Jammu\& Kashmir & 0.3 & 0.42 & 1400 & 0.3 & 0.5 & 1667 \\
\hline Jharkhand & 0.16 & 0.27 & 1688 & 0.16 & 0.3 & 1875 \\
\hline Karnataka & 0.23 & 0.17 & 739 & 0.23 & 0.19 & 826 \\
\hline Assam & 0.05 & 0.06 & 1200 & 0.05 & 0.06 & 1200 \\
\hline Other & 0.14 & 0.24 & (a) & 0.13 & 0.25 & (a) \\
\hline All India & 29.7 & 92.5 & 3118 & 29.9 & 94.9 & 3177 \\
\hline
\end{tabular}

Source: Department of Agriculture and Cooperation 
Wheat is important cereal crop growing in Rabi season in India. Globally India is the second largest producer of wheat next to china in terms of area. Total area under wheat crop is about 29.7 million hectare in the country 2012-13. The production of wheat in the country has increased significantly from 75.81 million tons in 2006 to an all-time recorded high 94.9 million tons in 2011-12 and the productivity of wheat was found to be increase from 2602 $\mathrm{kg} / \mathrm{ha}(2004-05)$ to $3177 \mathrm{~kg} / \mathrm{ha}$ in $2011-12$ (table 1 ). The major increase in the productivity of wheat has been observed in the state of Haryana, Panjab and Uttar Pradesh. Madhya Pradesh stands on third position with 5.3 million ha area of wheat in the recent years.

Wheat is the major Rabi crop grown in the state of Madhya Pradesh covering 4.89 Million hectare area and 11.54 Million tons of production (2011-12). The total shares of wheat production of Madhya Pradesh state in India is $12.16 \%$ the average yield of Madhya Pradesh found to be near about $2360 \mathrm{~kg}$ per hectare. The district statistics witness of a sequence of technological changes in crop production particularly of wheat since the inception of green revolution. But the impacts of improved technology have not been so prominent now a day which can fulfill the requirement of wheat for increasing population of district. It is the fact that farmers have little control over production due to agriculture being seasonal and biological in characters resulted in low yield and consequently affects the profit of farmers. The study was conducted with specific objective viz. to estimate resource use efficiency of wheat production and to identify the constraints associates with wheat production and its measures for efficient production.

\section{Methodology}

The present study was confined to Betul district of Madhya Pradesh during the year 2013-14 as Betul is one of the tribal population districts of the State and having remarkable area of wheat in the state. One block of Betul district having higher concentration of wheat area and production has been selected purposively. A list of villages from the selected block was prepared with the help of RAEOs. Five villages viz. Suhagpur, Betul Bazar, Kalyanpur, Dhoul and Sakadhi were selected randomly. After selection of villages, the list of those farmers who were growing wheat crop was prepared and classified into 3 size group viz. small (up to 2 hectare), Medium (2-4 hectare), large (above 4 hectare). From each group 20 farmers were selected randomly. Thus, total of 60 farmers were selected for detailed investigations. This study was based on primary and secondary data. The primary data was collected with the help as pretested interview scheduled from selected farmers. The secondary data was collected from the different publications as well as district statistical office.

The resource use efficiency of wheat production was judged by fitting the Cobb-Douglas production function, before fitting the function the zero order correlation coefficients were estimated to test the multicollinearity among the explanatory variables. The specification of the Cobb- Douglas production function equation is as follows.

$$
\mathrm{Y}=\mathrm{aX}_{1}{ }^{\mathrm{b} 1} \mathrm{X}_{2}{ }^{\mathrm{b} 2} \mathrm{X}_{3}{ }^{\mathrm{b} 3} \mathrm{X}_{4}{ }^{\mathrm{b} 4} \mathrm{X}_{5}{ }^{\mathrm{b} 5}
$$

In the logarithmic form it is assumed a log linear equation as under

$$
\log Y=\log +b_{1} \log X+b_{2} \log X_{2}+b_{3} \log X_{3}
$$

where,

$\mathrm{y}=$ gross value of output (Main production + by

production)

$\mathrm{a}=$ constant

$b_{1}$ to $b_{5}=$ Regression coefficients for $X_{1}$ to $X_{5}$

$\mathrm{X}_{1}=$ Value of human labour (Rs)

$\mathrm{X}_{2}=$ Value of machine labour (Rs)

$\mathrm{X}_{3}=$ Value of seed (Rs)

$\mathrm{X}_{4}=$ Value of Fertilizer (Rs)

$\mathrm{X}_{5}=$ Value of Irrigation (Rs)

$\mathrm{e}=$ Random variable

Marginal value production (MVP)

$$
\text { MVP of } \mathrm{X}_{1}=b_{1} \frac{\text { Geometricment of } \mathrm{y}}{\text { Gemmetric mean of } \mathrm{X} 1}
$$

Where,

$b_{1}=$ Elasticity of production of $1^{\text {th }}$ variable

$\mathrm{y}=$ Gross income

$\mathrm{x}_{1}=$ Independent variable

Pxi $=$ Price of Pxi

\section{Result \&Discussion}

\subsection{Resource Use Efficiency of Wheat}

The table 2 shows that the values of coefficient of multiple determination $\left(\mathrm{R}^{2}\right)$ were found to be quite high in all farm size ( 95 to $99 \%$ ) which indicates that the selected form of the production function was best fitted and able to explain the all independent variables to an extent of 95.5, 95.2 and 99 per cent in small, medium, and large size farms, respectively. The sum of regression coefficient of selected variables was found 0.899 and 0.991 on overall and small farm respectively which shows decreasing return to scale. Whereas in medium and large farms it was found 1.195 and 1.212 indicating increasing return to scale. The values of coefficient of human labour (0.156), machine labour (0.687), seed $(0.146)$ and fertilizer $(0.176)$ were found to be positive and highly significant at overall level ([1]; [2]). The estimation of resource use efficiency revealed that the regression coefficients for machine labour and seed were found to be positive and significant and had value of 0.551 and 0.140 , respectively at small size farm. The coefficient of human labour, fertilizer, and irrigation were found positive and non-significant at small size farm, machine labour and seed were important factor and play significant role in wheat production for small size of farms. Resource use efficiency 
showed that the coefficients for machine labour (0.526) and irrigation (0.242) was found positive and highly significant for medium size farms. Human labour (0.214) seed (0.116) and fertilizer $(0.104)$ resources were found to be positive and non-significant in medium size of farms. In case of large size farm, all the explanatory variables were found positive and significant except seed. Human labour and irrigation was found significant at 10 percent level of probability and machine labour at 5 percent level of probability whereas, fertilizer was found significant at 1 percent level of significant. The coefficient of human labour (0.419) machine labour (0.370) and fertilizer (0.190) were positive and highly significant. Similar findings were also reported by [3], [4] and [5].

\subsection{Marginal Value Productivity of Wheat}

Marginal value productivity of resource of various inputs and their ratio to their respective prices for each size of farm are given in table 3. It was found that small size farm, the factors of production $\mathrm{X}_{2}, \mathrm{X}_{3}, \mathrm{X}_{4}$, and $\mathrm{X}_{5}$, had been underutilized, while factor $\mathrm{X}_{1}$ implying over-utilization leaving scope for their increased use on sample farm. In case of medium, large and overall size of farms, all the factors i.e. $\mathrm{X}_{1}, \mathrm{X}_{2}, \mathrm{X}_{3}, \mathrm{X}_{4}$ and $\mathrm{X}_{5}$ were found to be underutilized. The marginal value productivity of $X_{1}$ in small size farm was less than the unit price of respective input implying over utilization of this input and leaving scope for their increase use ([6] and [7]).

Table 2. Resource Use Efficiency of wheat crop under different size group.

\begin{tabular}{|c|c|c|c|c|c|c|c|c|}
\hline \multirow{3}{*}{ Size group } & \multirow{3}{*}{ Intercept } & \multicolumn{5}{|c|}{ Production elasticity of variable } & \multirow{3}{*}{$\Sigma$ bi } & \multirow{3}{*}{$\mathrm{R}^{2}$} \\
\hline & & $\mathrm{X}_{1}$ & $\mathrm{X}_{2}$ & $\mathrm{X}_{3}$ & $\mathrm{X}_{4}$ & $\mathrm{X}_{5}$ & & \\
\hline & & $\begin{array}{c}\text { Human } \\
\text { labour }\end{array}$ & Machine labour & Seed & Fertilizer & Irrigation & & \\
\hline Small & $\begin{array}{l}14.157 \\
(0.506)\end{array}$ & $\begin{array}{c}0.088 \\
(0.222)\end{array}$ & $\begin{array}{c}0.551^{* *} \\
(0.270)\end{array}$ & $\begin{array}{c}0.140 \\
(0.086)\end{array}$ & $\begin{array}{c}0.100 \\
(0.171)\end{array}$ & $\begin{array}{c}0.110 \\
(0.213)\end{array}$ & 0.991 & 0.955 \\
\hline Medium & $\begin{array}{c}1.615 \\
(1.847) \\
\end{array}$ & $\begin{array}{c}0.214 \\
(0.369) \\
\end{array}$ & $\begin{array}{l}0.526^{* *} \\
(0.261) \\
\end{array}$ & $\begin{array}{c}0.116 \\
(0.232) \\
\end{array}$ & $\begin{array}{c}0.104 \\
(0.660) \\
\end{array}$ & $\begin{array}{c}0.242 \\
(0.162) \\
\end{array}$ & 1.195 & 0.952 \\
\hline Large & $\begin{array}{c}1.023 \\
(0.672)\end{array}$ & $\begin{array}{l}0.419^{*} \\
(0.240)\end{array}$ & $\begin{array}{c}0.370^{* *} \\
(0.163)\end{array}$ & $\begin{array}{c}0.079 \\
(0.189) \\
\end{array}$ & $\begin{array}{c}0.190 * * * \\
(0.058)\end{array}$ & $\begin{array}{l}0.162 * \\
(0.092)\end{array}$ & 1.212 & 0.990 \\
\hline Overall & $\begin{array}{l}30.188 \\
(0.090)\end{array}$ & $\begin{array}{l}0.156^{*} \\
(0.088)\end{array}$ & $\begin{array}{c}0.687 * * * \\
(0.099)\end{array}$ & $\begin{array}{c}0.146 * * * \\
(0.055)\end{array}$ & $\begin{array}{c}0.176 * * * \\
(0.045)\end{array}$ & $\begin{array}{c}0.049 \\
(0.054)\end{array}$ & 0.899 & 0.991 \\
\hline
\end{tabular}

Figures parentheses shows the stander error of concerned regression coefficient $\left(*, * *\right.$ and ${ }^{* * *}$ indicates $10,5,1$ per cent level of significance respectively.)

Table 3. Marginal value productivity of resources

\begin{tabular}{|c|c|c|c|c|c|}
\hline Input & Price & Small & Medium & Large & Overall \\
\hline $\mathrm{X}_{1}$ & $20 / \mathrm{Hr}$ & 0.6943 & 1.5847 & 3.4603 & 1.2249 \\
\hline $\mathrm{X}_{2}$ & $850 / \mathrm{Hr}$ & 5.1628 & 3.8927 & 2.6095 & 5.4067 \\
\hline $\mathrm{X}_{3}$ & $18 / \mathrm{kg}$ & 3.9847 & 3.1362 & 1.8940 & 3.8546 \\
\hline $\mathrm{X}_{4}$ & $16 / \mathrm{kg}$ & 1.6770 & 1.7484 & 3.2944 & 2.9727 \\
\hline $\mathrm{X}_{5}$ & $70 / \mathrm{Hr}$ & 2.8875 & 5.1076 & 2.9909 & 1.0582 \\
\hline
\end{tabular}

Table 4. Constraints associate with wheat production

\begin{tabular}{|c|c|c|c|c|c|c|c|c|c|c|}
\hline \multirow{3}{*}{ S. No. } & \multirow{3}{*}{ Constraints } & \multicolumn{9}{|c|}{ Size of group } \\
\hline & & \multicolumn{2}{|c|}{ Small } & \multicolumn{2}{|c|}{ Medium } & \multicolumn{2}{|c|}{ Large } & \multicolumn{2}{|c|}{ Overall } & \multirow{2}{*}{ Rank } \\
\hline & & No. & $\%$ & No. & $\%$ & No. & $\%$ & No. & $\%$ & \\
\hline 1. & Unavailability of quality seed & 12 & 60 & 10 & 50 & 8 & 40 & 30 & 50 & VI \\
\hline 2. & Lack of knowledge of seed rate & 12 & 60 & 11 & 55 & 6 & 30 & 29 & 48 & VII \\
\hline 3. & Higher price of quality seed & 16 & 80 & 14 & 70 & 11 & 55 & 41 & 68 & I \\
\hline 4. & $\begin{array}{l}\text { Lack of knowledge of dose for seed } \\
\text { treatment and it procedure }\end{array}$ & 16 & 80 & 10 & 50 & 7 & 35 & 33 & 55 & IV \\
\hline 5. & $\begin{array}{l}\text { Lack of knowledge of nutrient } \\
\text { content of the different fertilizers }\end{array}$ & 16 & 80 & 13 & 65 & 11 & 55 & 40 & 67 & II \\
\hline 6. & Higher price of fertilizers & 14 & 70 & 12 & 60 & 10 & 50 & 36 & 60 & III \\
\hline 7. & $\begin{array}{l}\text { Lack of knowledge about } \\
\text { recommended dose of fertilizer }\end{array}$ & 12 & 60 & 10 & 50 & 6 & 30 & 28 & 46 & IX \\
\hline 8. & $\begin{array}{l}\text { Lack of timely availability of desire } \\
\text { fertilizer. }\end{array}$ & 14 & 70 & 12 & 60 & 6 & 30 & 32 & 53 & V \\
\hline 9. & $\begin{array}{c}\text { Higher price of insecticide and } \\
\text { pesticides }\end{array}$ & 10 & 50 & 8 & 40 & 7 & 35 & 25 & 42 & $\mathrm{X}$ \\
\hline 10. & $\begin{array}{l}\text { Lack of market information about } \\
\text { input and output }\end{array}$ & 12 & 60 & 9 & 45 & 7 & 35 & 28 & 47 & VIII \\
\hline 11. & $\begin{array}{l}\text { Lack of visit and advice of extension } \\
\text { other agencies for transfer of } \\
\text { technology }\end{array}$ & 10 & 50 & 8 & 40 & 5 & 25 & 23 & 38 & XI \\
\hline
\end{tabular}




\subsection{Constraints Associates with Wheat Production}

An attempt was also undertaken to find out the various constraints, which faced by the farmers during production of wheat in the study area and are presented in the table 4 . The majority of wheat growers reported that high price of quality seed was the main constraints $(68 \%)$ followed by lack of knowledge about nutrient content in different fertilizer $(67 \%)$, high price of fertilizer $(60 \%)$, lack of knowledge about doses for seed treatment and its procedure (55\%), lack of timely availability of necessary inputs $(53 \%)$ and non-availability of quality seed (50\%) and lack of knowledge of recommended seed rate faced by the sample respondents in the study area. Among the size group more problems was related to seed of selected crops. The participation of extension or other agencies for adoption of improved technology $50 \%$ of small farm reported that these agencies are not function properly in the study area [8].

\section{Conclusions}

On the basic of above finding it can be concluded that the resource use efficiency of human labour on large farms and overall sample farms as well as machine labour on small, medium and large farms were found positive and significant. Whereas, the efficiency of other resources like seed in overall farms, fertilizer on large farms and overall farms and irrigation in large farms were found positive and significant. It indicates further scope of applying these input for augmenting production and profitability from wheat production on sample farms. The marginal value productivity of $X_{1}$ for small size farm was indicate less than the unit price of respective input implying overutilization of this input and leaving scope for their increased use. It is also concluded that the farmer of small group was facing more problem as compared to medium and large group pertaining to resource use efficiency.

\section{REFERENCES}

[1] Barman, R. N. and Kumar, P. (1998) Resource use efficiency in wheat production, a study in Nalbari district. Assam. Crop Research Hissar, 16 (1):115-119.

[2] Banafer, K. N .S. and Thakur, M. K. (2005) Resource use efficiency in irrigation mustard an: economic analysis of Surguja district of Chhattisgarh. Indian Journal of Agriculture Economics, 60 (3): 547-548.

[3] Akighir, D.T. (2011) Efficiencies of Resource use in Rice farming enterprise in kwande local Government area of Benue State, Nigeria, International Journal of Humanities and Social Science. 1(3): 215-220.

[4] Haque, T. (2006) Resource uses efficiency in Indian Agriculture. Indian Journal of Agril. Econ. 61 (2): 65-75.

[5] Dhaliwal, N. S. Grover D. K. and Bawa, R. S. (2004) Resource use efficiency in wheat crop in different agro- climatic zones of Punjab. Journal of Research Vol. 41 (3) pp. 392-401.

[6] Sarawgi, A. K., Beohar, B. B., and Tiwari, D. N. (1992) Resource productivity and resources adjustment in wheat production in Malwa Plateu, Madhya Pradesh, Ind. J. of Agril. Econ. 47 (3):513.

[7] Singh, V. V., Gupta, D. D., and Singh, H. (1992) Input uses efficiency in wheat crops in Haryana, Indian J. of Agril. Econ. $47(8) 50$.

[8] Khan, I., Ullah, Jan, A., Gul, F., Ali, K. and Ahmad, N. (2011) Weeds as a major constraint in wheat production in district Peshawar Pak. J. Weed Sci. Res. 17(4):381-386. 